\title{
Impact of the ambient air quality due to the dispersion of non-methane organic compounds from Barka Landfill
}

\author{
S. A. Abdul-Wahab ${ }^{1}$ A. Al-Hajri ${ }^{1} \cdot$ K. Yetilmezsoy $^{2}$
}

Received: 4 September 2015/Revised: 23 January 2016/Accepted: 8 February 2016/Published online: 22 February 2016

(C) Islamic Azad University (IAU) 2016

\begin{abstract}
This study used the CALPUFF modeling system to study the impact of an area's geophysical and meteorological conditions on the dispersion of nonmethane organic compounds (NMOCs) into the atmosphere from the 17-year-old Barka Landfill. Barka Landfill is located in Barka, Batinah, in the north of the Sultanate of Oman. It receives waste from nearby regions such as Nakhal, Seeb, and Wadi Al-Maawel, affecting the town of Barka with landfill gas (LFG) pollution. The present study was conducted to evaluate the impact of the air dispersion of one group of NMOC gases on Barka and the region around it. The top five values of the concentrations with different average time periods, namely 1,3 and $23 \mathrm{~h}$, were compared with the allowable emission rate defined by the US Environmental Protection Agency (EPA). The results demonstrated that the present integrated modeling system (consisting of a 3D diagnostic CALMET model and Lagrangian puff dispersion CALPUFF model) could be utilized as a useful tool for evaluating the top five peak values of the NMOC emissions of the different time periods.
\end{abstract}

Keywords CALPUFF - Dispersion - Landfill · Modeling · Non-methane organic compounds

S. A. Abdul-Wahab

sabah1@squ.edu.com

1 Department of Mechanical and Industrial Engineering, Sultan Qaboos University, P.O Box 33, 123 Muscat, Oman

2 Department of Environmental Engineering, Faculty of Civil Engineering, Yildiz Technical University, 34220 Davutpasa, Esenler, Istanbul, Turkey

\section{Introduction}

Landfill gases (LFG) are formed by the breakdown of municipal solid waste (MSW) by bacteria. LFG consist of 40-60\% carbon dioxide $\left(\mathrm{CO}_{2}\right), 45-60 \%$ methane $\left(\mathrm{CH}_{4}\right)$, and a small percentage of volatile organic compounds (VOCs) and hazardous air pollutants (HAPs). LFG can also comprise non-methane organic compounds (NMOCs). Many studies have found around 100 different compounds at inspected sites (Gendebien and Pauwels 1992), including toluene $\left(\mathrm{C}_{7} \mathrm{H}_{8}\right)$, vinyl chloride $\left(\mathrm{H}_{2} \mathrm{C}=\mathrm{CHCl}\right)$, benzene $\left(\mathrm{C}_{6} \mathrm{H}_{6}\right)$, ethyl benzene $\left(\mathrm{C}_{6} \mathrm{H}_{5} \mathrm{CH}_{2} \mathrm{CH}_{3}\right)$, xylenes $\left(\mathrm{C}_{8} \mathrm{H}_{10}\right)$, ethane $\left(\mathrm{C}_{2} \mathrm{H}\right)$, butane $\left(\mathrm{C}_{4} \mathrm{H}_{10}\right)$. NMOCs are subjected to various processes within the waste and cover soil of the landfill, such as volatilization, biodegradation, or adsorption. These processes consequently manage their fate inside the landfill and their eventual release into the atmosphere.

High concentrations of LFG occur commonly in landfills that contain MSW and have an impermeable cover (US EPA 2005). Human exposure to LFG occurs through a primary pathway, the release of LFG to ambient air, which is most common when a permeable cover is used or when the cover has been breached either intentionally or unintentionally. In these conditions, the gas is transported by the internal pressure to the surface of the landfill or through passive openings to the air around the landfill. Human exposure may occur on or off site as a function of the emission rate and atmospheric dispersion. The consequence of the human exposure to the LFG is determined by the toxicity of the gas that is present and its concentration, as well as by the duration and frequency of exposure. Duration and frequency of exposure are functions of the LFG emission rate, the atmospheric dispersion, and the demographics of those living within proximity to the landfill (www.nepis.epa.gov). Among atmospheric pollutants, LFG are regarded as the major cause 


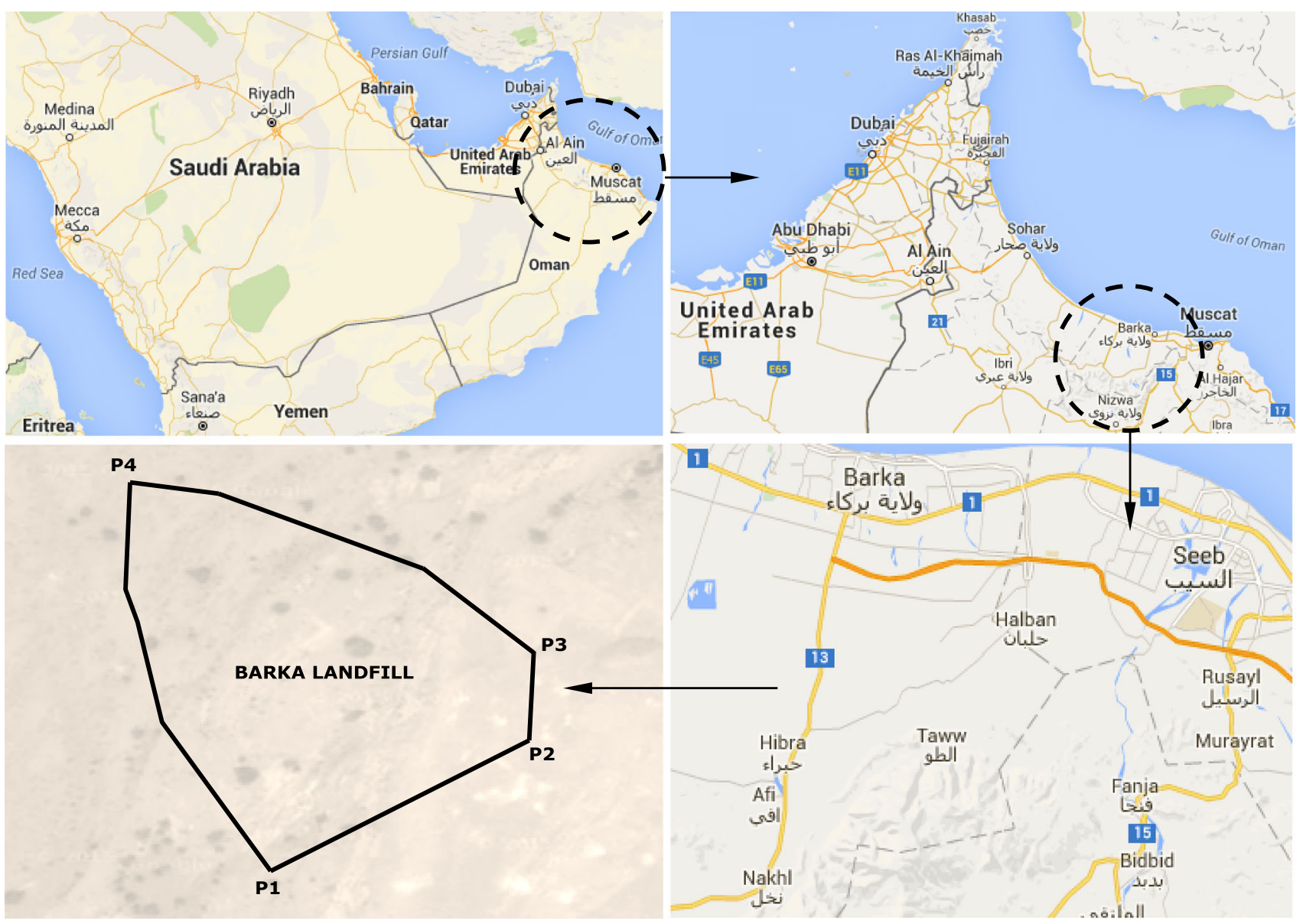

Fig. 1 Map of the landfill area

of complaints made to local authorities (Leonardos 1996; Schiffman and Williams 2005; Henshaw et al. 2006).

A number of modeling approaches can be used for the examination of atmospheric dispersion. CALPUFF (California Puff) model was approved by the US Environmental Protection Agency (EPA) as a useful tool to determine atmospheric dispersion, especially in areas with pollution sources such as landfills. Wang et al. (2006) compared CALPUFF and ISCST (industrial source complex short term) models for the dispersion of odor, concluding that CALPUFF could anticipate reasonably well the average odor concentrations downwind. Elbir et al. (2007) predicted odor levels' concentrations around a meat packaging and rendering plant using CALPUFF. Many other studies have successfully examined dispersion modeling in landfills (Leonardos 1996; Schiffman and Williams 2005; Ubeda et al. 2010; Zhu et al. 2013; Mønster et al. 2015). Ubeda et al. (2010) examined the impact of the odor from a landfill and waste treatment facility through the application of two dispersion models: geographic information system
(GIS) tools and a commercial bi-Gaussian atmospheric dispersion model.

In consideration of the foregoing facts, the present work aims to determine the concentration of NMOCs emitted from Barka Landfill. Moreover, this study sought to examine the impacts of geophysical and meteorological conditions (surface data and upper air data) in the dispersion of NMOCs from the proposed landfill. It was expected that the different metrological conditions for winter and summer would result in different concentrations of NMOCs.

\section{Materials and methods}

\section{Study area and timing}

Barka is located at $\mathrm{N} 23^{\circ} 42^{\prime} 33^{\prime \prime}$ and E57 $53^{\prime} 13^{\prime \prime}$, which is to the north of Oman's capital city, Muscat, and has an area of $1350 \mathrm{~km}^{2}$ (Rajmohan et al. 2007). A natural border from the north is created by the Sea of Oman, 
Table 1 Parameters defining Barka Landfill

\begin{tabular}{ll}
\hline Parameter & Value \\
\hline P1 Coordinate $(\mathrm{km})$ & $(0,-0.08)$ \\
P2 Coordinate $(\mathrm{km})$ & $(0.099,-0.01996)$ \\
P3 Coordinate $(\mathrm{km})$ & $(0.1004,0.03069)$ \\
P4 Coordinate $(\mathrm{km})$ & $(-0.05408,0.106)$ \\
Initial sigma $(\mathrm{m})$ & 2.5 \\
Effective height $(\mathrm{m})$ & 8 \\
Base elevation $(\mathrm{m})$ & 17 \\
\hline
\end{tabular}

while the watershed of the Jabal Al-Akdar and Nakhal Mountains girdles the south. The hills in the southern part of the study region have steep slopes with little soil cover and no vegetation. In general, the area of the study experiences dry climatic conditions with high rates of evapotranspiration (Rajmohan et al. 2009). The average annual air temperature is approximately $28.5^{\circ} \mathrm{C}$ in the coastal area and $17.8^{\circ} \mathrm{C}$ in the mountains. Rainfall is extremely variable with respect to space and time. The area of the landfill is slightly triangular as shown in Fig. 1 and Table 1. The coordinates which are shown in the figure are the coordinates of the landfill. Some data which are required to run the model such as initial sigma, effective height, and the base elevation are shown in Table 1. Sampling times occurred on the 2 January between 00:00 and 23:00 (winter) and the 2 June between 00:00 and 23:00 (summer) to show the difference in the concentration in two different seasons.

\section{Landfill selection}

The selection process for the site to be studied was based on two requirements: a sufficient number of regions and wilayats, or districts, served by the landfill and a sufficient number of households surrounding the source. Muscat
Municipality indicated via a questionnaire that Barka Landfill receives different types of waste mainly from three cities: Barka, Nakhal, and Wadi Al-Maawil, with a total population of approximately 150,000 people, qualifying it for the present study. The number of population that can be affected in only Barka area itself is 103,629.

Barka Landfill is very large and unregulated and is located about $8 \mathrm{~km}$ south of Barka, near the road connecting Barka and Nakhal. Barka Landfill receives waste from houses, governmental establishments, industries, medical facilities, and other commercial establishments in Seeb, Nakhal, Wadi Al-Maawil, and Barka town (magazine.geotunis.org).

The landscape of the area around the Barka Landfill is flat and crossed by a wadi, or dry riverbed, at one edge. A site visit revealed that the landfill is relatively close to a

Table 3 Details of the station used to obtain the surface data and the upper air data

\begin{tabular}{ll}
\hline Type of data & Surface raw data \\
\hline Station name & Muscat metrological station \\
Latitude & 23.58 \\
Longitude & 58.28 \\
Elevation & 17 \\
WBan & 99,999 \\
WMO ID & 41,256 \\
INIT & OOMS \\
Type of data & Upper air raw data \\
Station name & Abu Dhabi Intl 99AE \\
Latitude & 24.43 \\
Longitude & 54.65 \\
Elevation & 27 \\
WBan & 99,999 \\
WMOID & 41,217 \\
INIT & OMAA
\end{tabular}

Table 2 Methane potential values for different types of waste

\begin{tabular}{llllr}
\hline Components & $\begin{array}{l}\text { Weight } \\
(\mathrm{kg})\end{array}$ & $\begin{array}{l}\text { Percentage } \\
(\%)\end{array}$ & $\begin{array}{l}\text { Methane potential }\left(\mathrm{m}^{3} \text { of } \mathrm{CH}_{4} / \text { ton of }\right. \\
\text { waste })\end{array}$ & Average \\
\hline $\begin{array}{l}\text { Food scrap, vegetables and } \\
\text { fruits }\end{array}$ & 320 & 0.43 & 70 & 30.15 \\
Grass and tress rests & 103 & 0.14 & 45 & 6.24 \\
Papers & 30 & 0.04 & 50.5 & 2.04 \\
Cardboard & 105 & 0.14 & 40 & 5.65 \\
Plastic & 70 & 0.09 & 50 & 4.71 \\
Textiles & 36 & 0.05 & 30 & 1.45 \\
Wood & 29 & 0.04 & 61.5 & 2.40 \\
Leather rubber & 20 & 0.03 & 12.5 & 0.34 \\
Glass stone & 30 & 0.04 & 56 & 2.26 \\
Total & 743 & 1.00 & N/A & 55.24 \\
\hline
\end{tabular}


Table 4 Shared information identification

Table 5 Average winter time concentrations of NMOC at different periods of exposure

\begin{tabular}{ll}
\hline Parameter & Values \\
\hline Projection & Lambert conformal conic (LCC) \\
Origin latitude & $23.6 \mathrm{~N}$ \\
Origin longitude & $58.0 \mathrm{E}$ \\
Latitude 1 & $5 \mathrm{~N}$ \\
Latitude 2 & $40 \mathrm{~N}$ \\
False easting & 0 \\
False northing & 0 \\
Continent & GLOBAL \\
Datum code & WGS-84 \\
Geoid-ellipsoid & WGS-84: WGS84 \\
X (easting) & -100 \\
Y (northing) & -100 \\
No. of X grid cells & 200 \\
No. of Y grid cells & 200 \\
Grid spacing & 1 km \\
No. of vertical layers & 10 \\
Height of vertical layers (m) & $0,20,40,80,160,320,700,1300,1700,2300,3000$ \\
Base time zone & UTC + 400 \\
Modeling period (Summer) & Start at time 00:00, end 23:00 June 2, 2013 \\
Modeling period (Winter) & Start at time 00:00, end 23:00 January 2, 2013 \\
\hline
\end{tabular}

\begin{tabular}{llll}
\hline Receptors & Coordinates $(\mathrm{km})$ & Time $(\mathrm{HH}: \mathrm{MM})$ & $\begin{array}{l}\text { Concentration } \\
\text { value }\left(\mu \mathrm{g} / \mathrm{m}^{3}\right)\end{array}$
\end{tabular} $\begin{aligned} & \begin{array}{l}\text { Allowable } 24-\mathrm{h} \\
\text { concentration }\left(\mu \mathrm{g} / \mathrm{m}^{3}\right)\end{array}\end{aligned}$

Winter top 5 1-h average concentrations

$\begin{array}{lccll}\text { R1 } & (0.5,-0.5) & 22: 00 & 1.77 & 4.69 \\ \text { R2 } & (-0.5,-0.5) & 01: 00 & 1.14 & \\ \text { R3 } & (-1.5,-0.5) & 04: 00 & 0.50 & 0.34 \\ \text { R4 } & (-0.5,-0.5) & 05: 00 & 0.23 & 4.69 \\ \text { R5 } & (-1.5,-0.5) & 03: 00 & \\ \text { Winter top 5 } & \text { 3-h average concentrations } & 0.43 & \\ \text { R1 } & (-0.5,-0.5) & 00: 00 & 0.25 & \\ \text { R2 } & (-1.5,-0.5) & 03: 00 & 0.13 \\ \text { R3 } & (0.5,-3.5) & 18: 00 & 0.11 & \\ \text { R4 } & (-0.5,-0.5) & 03: 00 & 0.07 \\ \text { R5 } & (0.5,-1.5) & 15: 00 & \\ \text { Winter top 5 } & 23-h \text { average concentrations } & 0.089 \\ \text { R1 } & (0.5,-0.5) & 00: 00 & 0.074 \\ \text { R2 } & (-0.5,-0.5) & 00: 00 & 0.032 \\ \text { R3 } & (-1.5,-0.5) & 00: 00 & 0.020 \\ \text { R4 } & (0.5,-3.5) & 00: 00 & 0.019 \\ \text { R5 } & (0.5,-1.5) & 00: 00 & \end{array}$

residential area, with the nearest household situated about $2 \mathrm{~km}$ to the north. The industrial area of Barka, covering about $0.2 \mathrm{~km}^{2}$, is $1 \mathrm{~km}$ away from the landfill, making LFG a potential major health risk to the people living in the industrial area.

\section{Emission rate data}

Emission rate data are one of the major types of data entered into CALPUFF. The results reflecting the NMOC emissions detected every $0.5 \mathrm{~km}$ are shown in tables and 
Table 6 Average summer time concentrations of NMOC at different periods of exposure

\begin{tabular}{lccll}
\hline Receptors & Coordinates $(\mathrm{km})$ & Time $(\mathrm{HH}: \mathrm{MM})$ & $\begin{array}{l}\text { Concentration } \\
\text { value }\left(\mu \mathrm{g} / \mathrm{m}^{3}\right)\end{array}$ & $\begin{array}{l}\text { Allowable 24-h } \\
\text { concentration }\left(\mu \mathrm{g} / \mathrm{m}^{3}\right)\end{array}$ \\
\hline Summer top 5 & 1-h average concentrations & & 4.69 \\
R1 & $(1.5,-0.5)$ & $04: 00$ & 0.85 & \\
R2 & $(0.5,-0.5)$ & $19: 00$ & 0.60 & \\
R3 & $(1.5,-0.5)$ & $22: 00$ & 0.50 & \\
R4 & $(1.5,-0.5)$ & $01: 00$ & 0.44 & 4.69 \\
R5 & $(2.5,0.5)$ & $03: 00$ & 0.25 & \\
Summer top 5 3 -h average concentrations & & \\
R1 & $(1.5,-0.5)$ & $03: 00$ & 0.320 & \\
R2 & $(0.5,-0.5)$ & $18: 00$ & 0.230 & \\
R3 & $(1.5,-0.5)$ & $00: 00$ & 0.150 & \\
R4 & $(2.5,-0.5)$ & $03: 00$ & 0.098 & \\
R5 & $(2.5,0.5)$ & $03: 00$ & 0.089 & \\
Summer top 5 $23-\mathrm{h}$ average concentrations & & \\
R1 & $(1.5,-0.5)$ & $00: 00$ & 0.085 & \\
R2 & $(0.5,-0.5)$ & $00: 00$ & 0.051 & \\
R3 & $(2.5,-0.5)$ & $00: 00$ & 0.019 & \\
R4 & $(2.5,-1.5)$ & $00: 00$ & 0.017 & \\
R5 & $(2.5,0.5)$ & $00: 00$ & 0.011 & \\
\hline
\end{tabular}

figures. The rate of emission of NMOC gases may be obtained by the following equation:

$C=2 \cdot L \cdot R \cdot\left(e^{-\mathrm{kc}}-e^{-\mathrm{kt}}\right)\left(C_{\mathrm{t}}\right)\left(3.6 \times 10^{-9}\right)$

where $L$ is the methane potential $\left(\mathrm{m}^{3} \mathrm{CH}_{4} /\right.$ ton of waste) given by the US EPA $\left(50 \mathrm{~m}^{3}\right.$ of $\mathrm{CH}_{4} /$ ton of waste as a default value), $R$ is the average acceptance rate ( $\mathrm{Mg} /$ year), $k$ is the methane generation rate, $c$ is the year since closure, $t$ is the duration of the landfill's existence (1995-2013, $t=17$ years), and $C_{\mathrm{t}}$ is the concentration of NMOC in ppm, as hexane $\left(\mathrm{C}_{6} \mathrm{H}_{14}\right)$. Herein, $C_{\mathrm{t}}=595 \mathrm{ppm}$, as a default value.

The methane potential $(L)$ for Barka Landfill is $74.4\left(\mathrm{~m}^{3}\right.$ $\mathrm{CH}_{4} /$ ton of waste). The methane generation rate $(k)$ ranges from 0.02 in dry conditions to 0.065 in wet conditions and has a default value of 0.05 year $^{-1}$. The years since closure of the landfill $(c)$ equals zero since the landfill is still active. Table 2 shows that the value of the methane potential was obtained as $74 \mathrm{~m}^{3} \mathrm{CH}_{4} /$ ton of waste to be used in Eq. (1). A total quantity of $743 \mathrm{~kg}$ was determined as shown in Table 2. A methane potential value of each type of waste was obtained, and the average of the methane potential was then calculated to be $55.24 \mathrm{~m}^{3} \mathrm{CH}_{4} /$ ton of waste as shown at the bottom of Table 2. The latter value was then subjected to a conversion to the quantity of waste $(1000 \mathrm{~kg})$, which yielded a value of $74 \mathrm{~m}^{3} \mathrm{CH}_{4} /$ ton of waste. The annual acceptance rate $(R)$ was determined according to the data given from the site by Muscat Municipality staff as an average of 11,577 tons of waste per year. Using 1-hour average concentration values in the summer period, the emission rate was determined to be $0.06663 \mathrm{~g} / \mathrm{s}$. The area of the landfill was measured and confirmed by the staff to be $216,950 \mathrm{~m}^{2}$. Therefore, the emission rate entered into CALPUFF was $3.0715 \times 10^{-7} \mathrm{~g} / \mathrm{m}^{2} / \mathrm{s}$.

\section{The US EPA's allowable NMOC emission rate}

The US EPA suggests that for every landfill that is 2.5 million Mg or above, NMOC emission rates must be calculated every year until a gas collection system is installed according to US EPA specifications. Equation (1) was approved by the US EPA for emission calculation. If the landfill's NMOC emission rate was evaluated to be equal to or greater than $50 \mathrm{Mg} / \mathrm{year}$, then a gas control system is required to lighten $\mathrm{NMOC}$ emissions. On the other hand, if NMOC emissions are found to be less than the allowable concentration (50 Mg/year), then the NMOC emission rate should be calculated annually (US EPA 1999). It is clear from the US EPA's statement that the allowable emission rate is $50 \mathrm{Mg} /$ year; therefore, according to the calculations for the emission rate which were conducted in Sect. 2.3, Barka Landfill's NMOC emission rate $(2.10 \mathrm{Mg} / \mathrm{year})$ is below the limit proposed by the US EPA.

\section{CALPUFF modeling}

CALPUFF is a non-stationary puff atmospheric dispersion model which has proven effective for the simulation of the dispersion of pollutants from a landfill area (Capelli et al. 
2011), but can be used to represent the effect of any type of pollution on a pre-identified area. The US EPA (2000) recommends CALPUFF for any long-range transport modeling due to its ability to handle complex three-dimensional (3D) wind field modeling (www.lungchicago. org). Puff models (Holmes and Morawska 2006; Barsotti et al. 2008; Cao et al. 2011) are an improvement over Gaussian plume models and can be applied to non-stationary and non-homogeneous flow by representing a plume by a series of independent elements (puffs) that evolve in time as a function of temporally and spatially varying meteorological conditions (Jung et al. 2003).

CALPUFF modeling requires three types of input: topographical (land use data and coastline data), meteorological, and emission data. The dimensions of grid on the domain of simulation are $200 \mathrm{~km} \times 200 \mathrm{~km}$, with $1-\mathrm{km}$ grid spacing.

Because the meteorological fields are considered important for air quality modeling, the use of site-specific meteorological data along with the input data generated by a meteorological model may increase the efficiency of the atmospheric dispersion model. The metrological data used for the simulation are from both the surface and upper air.

The surface data, provided by Seeb Meteorological Station in Muscat International Airport, were extracted from the whole data set from 2013. They include information about temperature, pressure, humidity, precipitation, wind direction, and wind speed for every hour of the 2 days chosen as representatives of the summer and winter seasons. These data were arranged into a file and formatted to be suitable for input into SMERGE, a CALPro processor for surface meteorological data. This file was processed using SMERGE to generate an output SURF.DAT file that can be comprehended and inputted into CALMET. On the other hand, the upper air data were obtained from radiosonde station records retrieved from the National Oceanic and Atmospheric Administration/Environmental Systems Research Institute (NOAA/ESRI) radiosonde data Web site from Abu Dhabi International Airport 99AE, OMAA.
$\operatorname{Jan} 02,2013$

22:00 LST(UTC+0400)

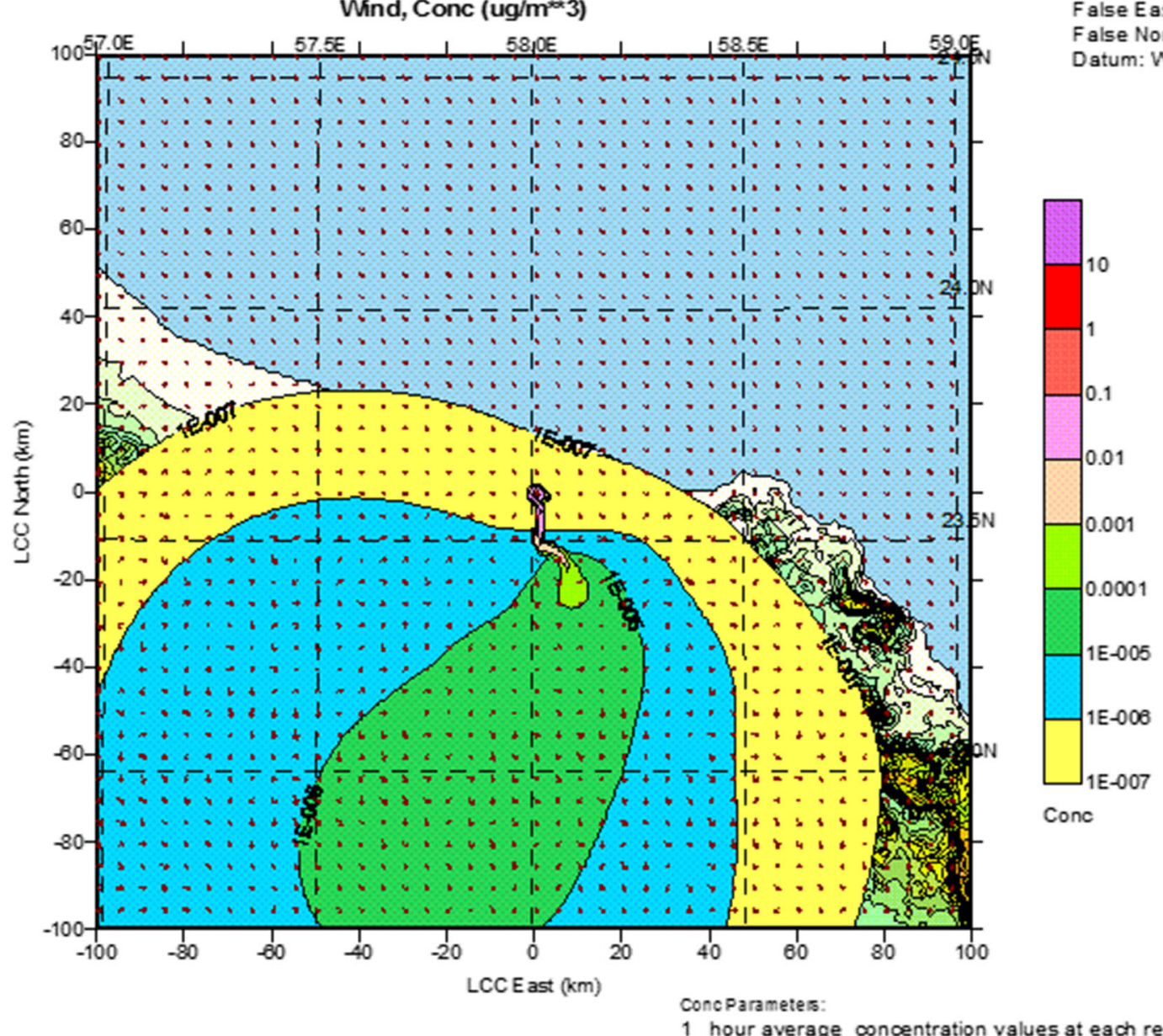

LCC Origin: $23.606 \mathrm{~N}, 58.008 \mathrm{E}$ Matching Parallels: $5 \mathrm{~N}, 40 \mathrm{~N}$

alse Easting: 0.0

alse Northing: 0.0

tum: WGS -84

Fig. 2 Winter 1-hour average concentration contour and the domain of the study at 22:00 
These data were arranged into a file and formatted to be suitable for input into READ62, a CALPro processor for upper air meteorological data. This file was processed using READ62 to produce an output UP.DAT file that can be comprehended and inputted into CALMET (AbdulWahab et al. 2014a, b). Details about the two stations used to acquire surface and upper air data are shown in Table 3.

The shared information need to be identified by the modeling tool CALPro before setting up geophysical and the metrological data. The data information includes the site's latitude and longitude, the domain of the study area, and vertical layers, and is shown in Table 4.

\section{Results and discussion}

The results of the present study are explained and divided into two parts: the average concentrations in winter (2 January, 00:00-23:00) and summer (2 June, 00:00-23:00).
In order to find out the average concentration for NMOCs emitted from Barka Landfill, CALPOST was used to calculate the average concentrations of NMOC based on the three durations of exposure: 1,3 , and $23 \mathrm{~h}$, at the five highest concentrations' coordinates. The modeled concentrations for NMOC were compared to Alberta Ambient Air Quality (AAAQ) Objectives for landfills. The comparison was made on the basis of the highest concentration predicted for each averaging period at each discrete receptor. The top five concentrations of NMOCs at each coordinate and the relevant air quality standard guideline indicating allowable concentration are shown in Tables 5 and 6 .

\section{Winter average concentrations}

Table 5 shows the top five average concentrations after $1 \mathrm{~h}$ of exposure. The table indicates that the limiting value of the allowable concentration based on the effect on human health and as quoted in the AAAQ is $4.69 \mu \mathrm{g} / \mathrm{m}^{3}$. Table 5
Jan 02, 2013

16:00 LST(UTC+0400)

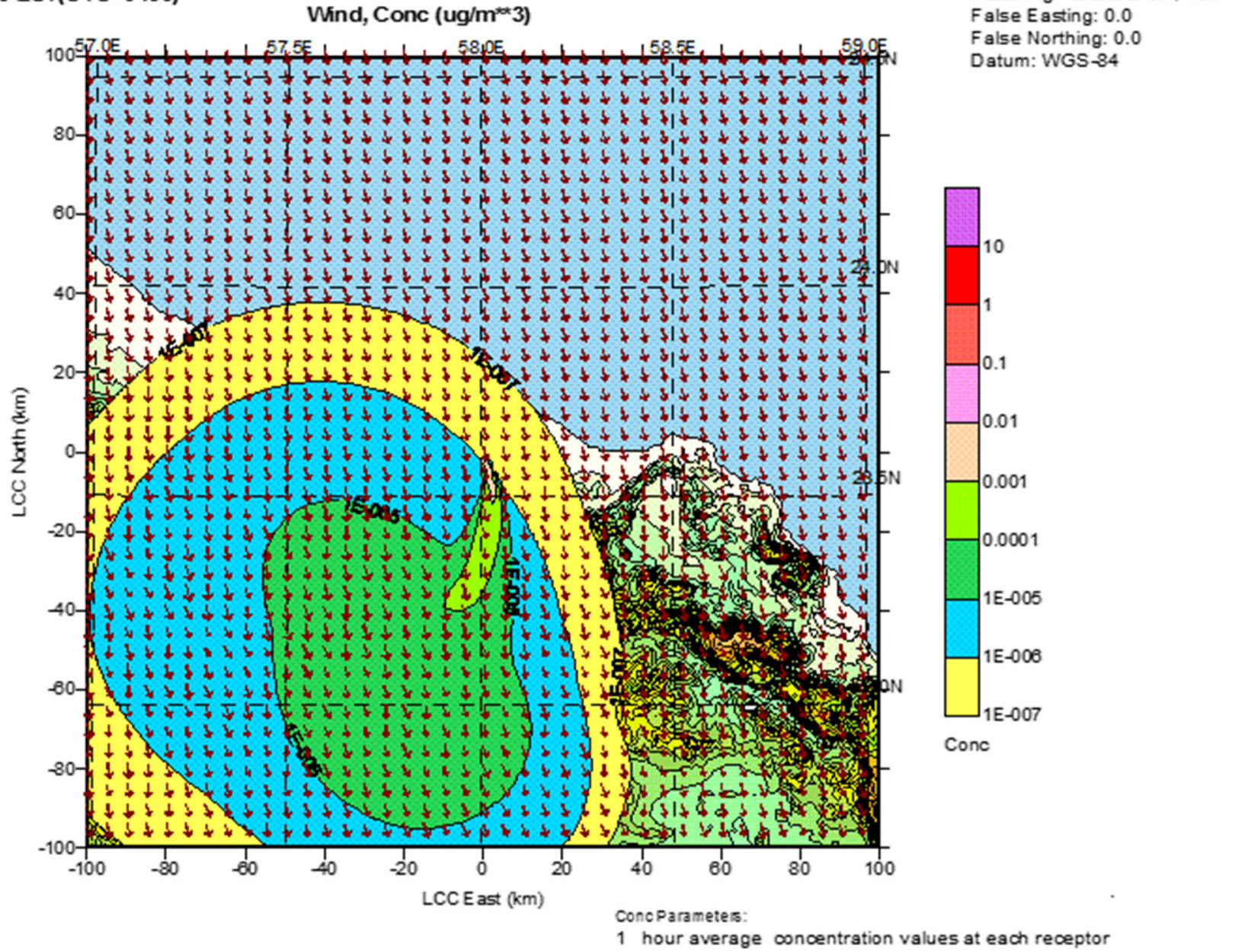

LCC Origin: $23.606 \mathrm{~N}, 58.008 \mathrm{E}$ Matching Parallels: $5 \mathrm{~N}, 40 \mathrm{~N}$ False Easting: 0.0

False Northing: 0.0

atum: WGS -84

1 hour average concentration values at each receptor

Fig. 3 Winter 1-hour average concentration contour and the domain of the study at 16:00 
shows that at all the coordinates of the top five receptors, the highest predicted concentration of NMOCs for the average period was low when compared to the AAAQ's allowable concentrations. The magnitude of concentration levels at receptors R1, R2, R3, R4, and R5 was $1.77,1.14$, $0.5,0.34$, and $0.23 \mu \mathrm{g} / \mathrm{m}^{3}$, respectively. The affected receptors were located within a range of $1.5 \mathrm{~km}$ from the landfill.

Figure 2 shows that the NMOC concentration value at the 1-h average period was high; it is represented in red (Table 5) and shows that the highest concentration peak value occurs at 22:00 with a value of $1.77 \mu \mathrm{g} / \mathrm{m}^{3}$. The wind direction in the represented domain was calm and did not blow in any one direction. However, the NMOC gas spread far from the landfill, exceeding the site's domain but with a very light concentration.

As can be similarly seen in Fig. 2, very light NMOC concentrations exceeded the domain of the study area. The wind direction at 16:00 on the 2 January is considered a factor in helping the gas to spread to residential areas around the landfill since the wind coming from the sea and land was blowing toward Barka town. The maximum concentration did not exceed $0.01 \mu \mathrm{g} / \mathrm{m}^{3}$.

The maximum ground level concentrations of NMOCs at the selected receptors for the average period of $3 \mathrm{~h}$ are given in Table 5. As discussed before, the emission rate for the NMOC emitted from Barka Landfill was below the AAAQ standards. Table 5 shows that the values of peak concentration were lower than the values of concentration for the 1-h period. Therefore, it can be said that the NMOC emitted from the landfill in the modeled day in winter did not affect the environment or the nearby households since the concentration peak values did not exceed the allowable limit of the 3-h average exposure. The values of concentration in the receptors R1, R2, R3, R4, and R5 have been tabulated and have values of $0.43,0.25,0.13,0.11$, and $0.07 \mu \mathrm{g} / \mathrm{m}^{3}$, respectively. Table 5 also represents the peak values of the top five concentration levels upon a $23-\mathrm{h}$
Jun 02, 2013

04:00 LST(UTC+0400)

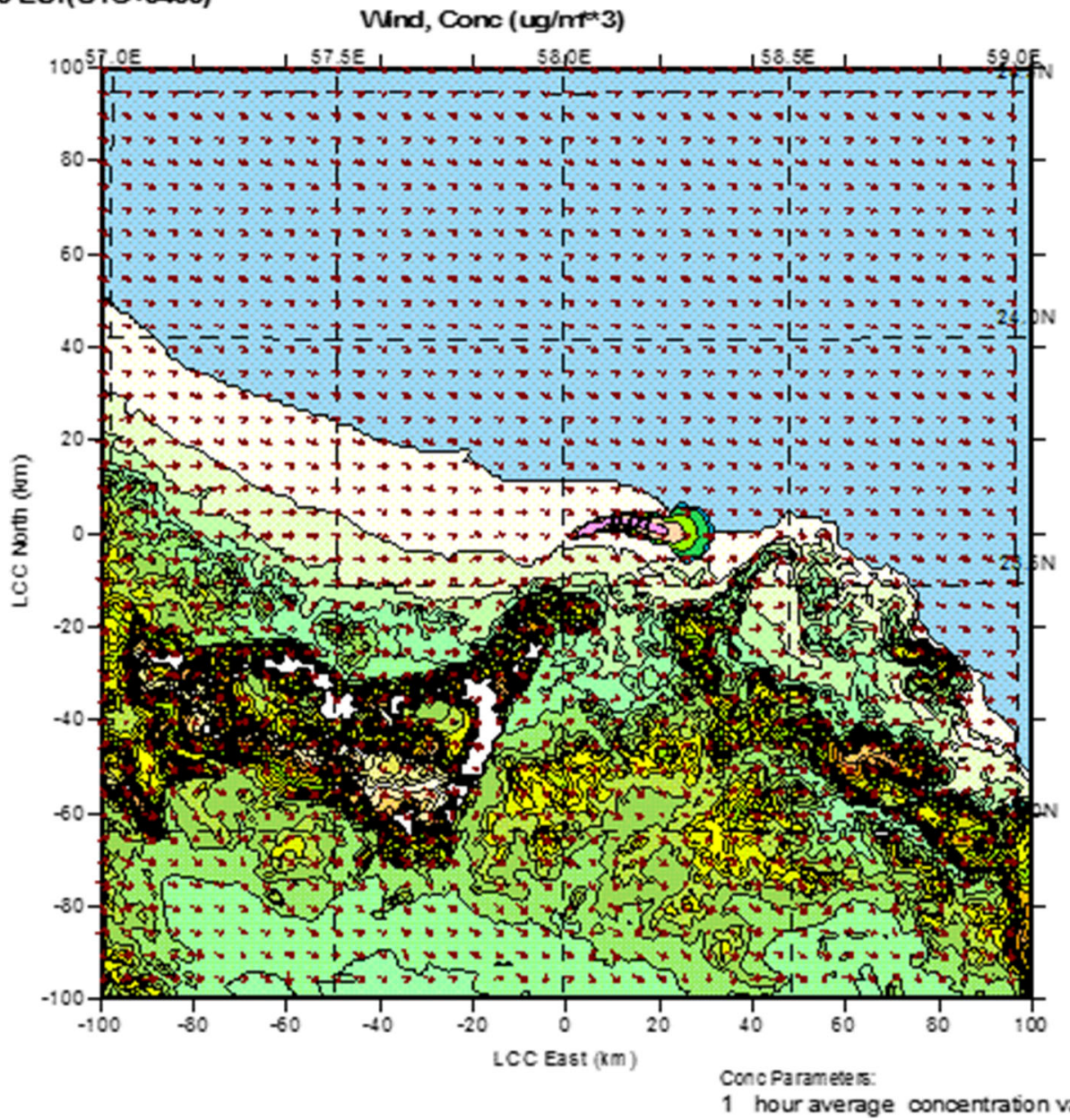

1 hour average
LCC Origin: $23.606 \mathrm{~N}, 58.008 E$ Matching Parallels $5 \mathrm{~N}, 40 \mathrm{~N}$ False E asting: 0.0 False Northing: 0.0 Datum: WGS-84

Fig. 4 Summer 1-hour average concentration contour and the domain of the study at 4:00 
average exposure. The values of the concentrations obtained by CALPOST for the receptors R1, R2, R3, R4, and R5 are 0.089, 0.074, 0.032, 0.02, and $0.019 \mu \mathrm{g} / \mathrm{m}^{3}$, respectively (Fig. 3).

\section{Summer average concentrations}

Table 6 shows that the concentrations of NMOCs are all less than the pre-defined limiting value of $4.69 \mu \mathrm{g} / \mathrm{m}^{3}$ determined by the AAAQ. Moreover, the maximum concentration values (Table 6) were reached in the early morning and evening hours. The concentration values in the receptors $\mathrm{R} 1, \mathrm{R} 2, \mathrm{R} 3, \mathrm{R} 4$, and $\mathrm{R} 5$ were $0.85,0.6,0.5$, 0.44 , and $0.25 \mu \mathrm{g} / \mathrm{m}^{3}$, respectively. Figure 4 shows the contour of the 1-h average concentration at 4:00 since the highest concentration $\left(0.85 \mu \mathrm{g} / \mathrm{m}^{3}\right)$ took place at that time. Moreover, the direction of the wind at that hour was mostly toward the sea (Fig. 4). At 22:00 in the same day of modeling, the spread of the NMOC gas was toward the interior due to a change in the wind direction. This was determined by the raw surface data file obtained from Seeb Metrological Station. In addition, the concentration of NMOC was high at the landfill and is represented in purple.

The concentration values of the NMOCs in the study area were very close to each other within the same average periods. In addition, all of the concentration values were below the standard limits set for NMOC as defined by the AAAQ. Table 6 shows that the values of the five top concentrations for the 3-h average exposure were less than the values of the concentration for the 1-h period. All the values were below the allowable concentrations, with peak values at the receptors of $0.32,0.23,0.15,0.098$, and $0.089 \mu \mathrm{g} / \mathrm{m}^{3}$. For the $23-\mathrm{h}$ average concentrations, the value of the concentrations decreased. The values of concentration reached their maximum at midnight, which was the first hour of modeling, at the receptors not exceeding $2.5 \mathrm{~km}$ from the landfill. The peak values of NMOC concentrations emitted from Barka Landfill for receptors R1,
Jun 02, 2013

22:00 LST(UTC+0400)

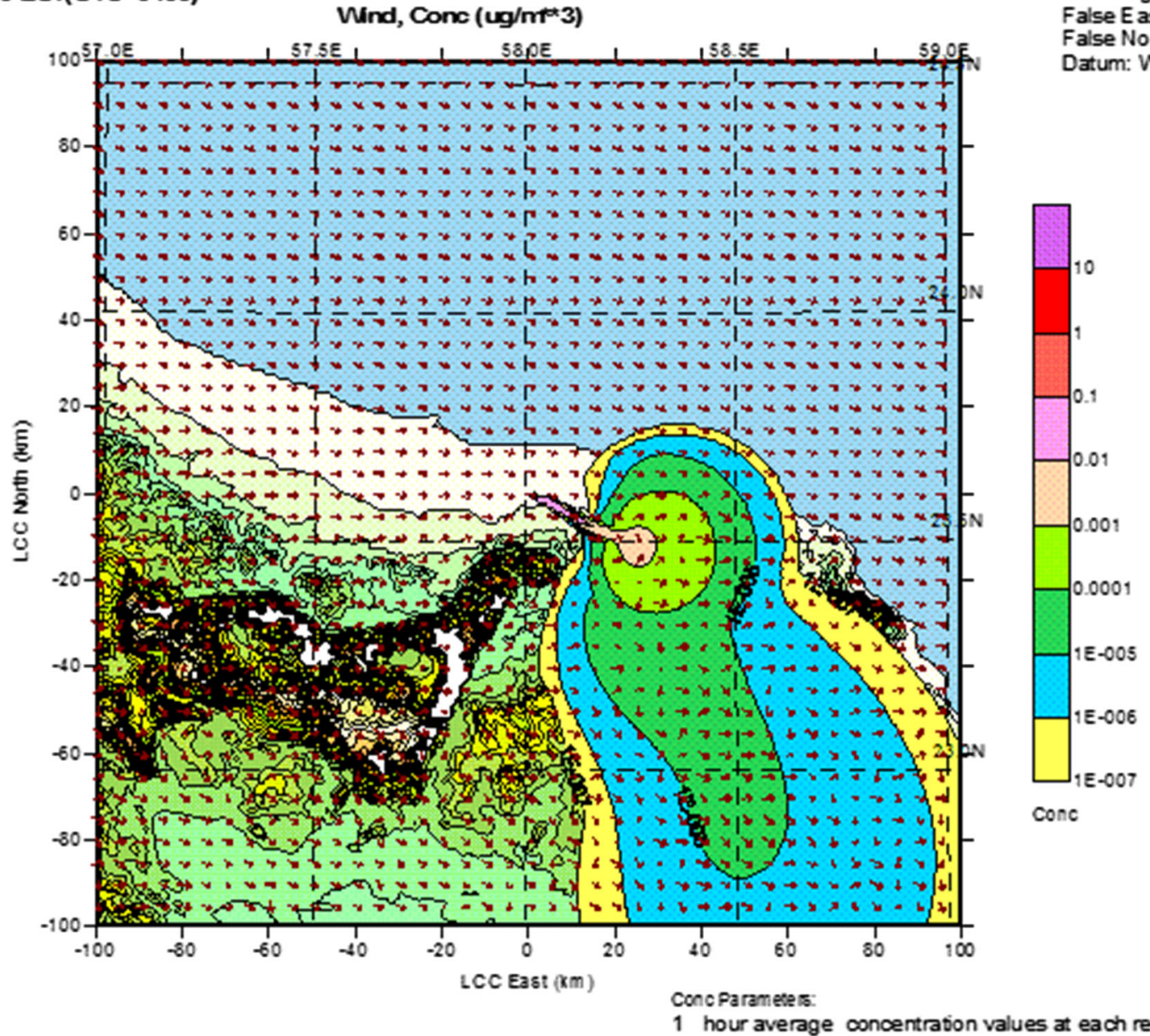

LCC Origin: 23.606N. $58.008 E$ Matching Parallels $5 \mathrm{~N}, 40 \mathrm{~N}$

ase Eating: 0.0

alse Northing: 0.0

atum: WGS-84

Fig. 5 Summer 1-hour average concentration contour and the domain of the study at 22:00 
R2, R3, R4, and R5 were 0.085, 0.051, 0.019, 0.017, and $0.011 \mu \mathrm{g} / \mathrm{m}^{3}$, respectively (Table 6; Fig. 5).

\section{Conclusion}

The present study was conducted in order to evaluate the NMOC concentrations emitted from Barka Landfill in the Sultanate of Oman. Additionally, the impact of the spread of NMOCs from the landfill was described. The top five peak values of the concentrations of different time periods (namely 1, 3 and $23 \mathrm{~h}$ ) were represented and tabulated with the coordinates where the highest concentrations occurred. Based on an integrated modeling system consisting of a 3D diagnostic CALMET model and Lagrangian puff dispersion CALPUFF model, the top five peak values of the concentrations of the different time periods were compared to the allowable value given by AAAQ. The results showed that the NMOC emissions were still low and within the defined limit. Based on this study, it can be stated that although Barka Landfill was approximately 17 years old at the time of this study, the NMOC emissions did not endanger the households in Barka or the regions around it.

Acknowledgments The authors wish to thank all who assisted in this work.

\section{Compliance with ethical standards}

Conflict of interest There is no conflict of interest declared by the authors.

\section{References}

Abdul-Wahab S, Chan K, Ahmadi L, Elkamel A (2014a) Impact of geophysical and meteorological conditions on the dispersion of $\mathrm{NO}_{2}$ in Canada. Air Qual Atmos Health 7(2):113-129

Abdul-Wahab S, Chan K, Ahmadi L, Elkamel A (2014b) Effects of metrological conditions on the dispersion of an accidental release of $\mathrm{H}_{2} \mathrm{~S}$ in Canada. Atmos Environ 82:316-326

Barsotti S, Neri A, Scire JS (2008) The VOL-CALPUFF model for atmospheric ash dispersal: 1. Approach and physical formulation. J Geophys Res Solid Earth 113(B03208):1-12

Cao X, Roy G, Hurley WJ, Andrews WS (2011) Dispersion coefficients for Gaussian plume models. Bound-Layer Meteor 139:487-500
Capelli L, Sironi S, Del Rosso R, Céntola P, Rossi A, Austeri C (2011) Odour impact assessment in urban areas: case study of the city of Terni. Procedia Environ Sci 4:151-157

Elbir T, Dincer F, Muezzinoglu A (2007) Evaluation of measured and predicted odor concentrations around a meat packaging and rendering plant personal environmental. Environ Eng Sci 24(3):313-320

Gendebien A, Pauwels M et al. (1992) Landfill gas: from environment to energy. Commission of the European Communities. EUR 14017/1 EN

Henshaw P, Nicell J, Sikdar A (2006) Parameters for the assessment of odour impacts on communities. Atmos Environ 40(6):1016-1029

Holmes NS, Morawska L (2006) A review of dispersion modelling and its application to the dispersion of particles: an overview of different dispersion models available. Atmos Environ 40(30):5902-5928

Jung YR, Park WG, Park OH (2003) Pollution dispersion analysis using the puff model with numerical flow field data. Mech Res Commun 30(4):277-286

Leonardos G (1996) Review of odor control regulations in the USA. In: Odors, Indoor and Environmental Air Proceedings of a Specialty Conference of the Air and Waste Management Association. Bloomington, MN, pp 73-84

Mønster J, Samuelsson J, Kjeldsen P, Scheutz C (2015) Quantification of methane emissions from 15 Danish landfills using the mobile tracer dispersion method. Waste Manag 35:177-186

Rajmohan N, Al-Futaisi A, Jamrah A (2007) Evaluation of long-term groundwater level data in regular monitoring wells, Barka, Sultanate of Oman. Hydrol Process 21(24):3367-3379

Rajmohan N, Al-Futaisi A, Al-Touqi S (2009) Geochemical process regulating groundwater quality in a coastal region with complex contamination sources: Barka, Sultanate of Oman. Environ Earth Sci 59(2):385-398

Schiffman SS, Williams CM (2005) Science of odor as a potential health issue. J Environ Qual 34(1):129-138

Ubeda Y, Ferrer M, Sanchis E, Calvet S, Nicolas J, Lopez PA (2010) Evaluation of odour impact from a landfill area and a waste treatment facility through the application of two approaches of a Gaussian dispersion model. In: International environmental modelling and software society (iEMSs), 2010 international congress on environmental modelling and software modelling for environment's sake, Fifth Biennial Meeting, Ottawa

US EPA (1999) United States Environmental Protection Agency, Municipal solid waste landfills. http://www.epa.gov/ttn/atw/ landfill/lf-vol1.pdf. Accessed 7 Dec 2015

Wang L, Parker DB, Parnell CB, Lacey RE, Shaw BW (2006) Comparison of CALPUFF and ISCST3 models for predicting downwind odor and source emission rates. Atmos Environ 40(25):4663-4669

Zhu H, Letzel MO, Reiser M, Kranert M, Bächlin W, Flassak T (2013) A new approach to estimation of methane emission rates from landfills. Waste Manag 33(12):2713-2719 